\title{
TATA CARA PENGITUNGAN BEA BALIK NAMA KENDARAAN BERMOTOR ( RODA DUA) DI KANTOR SAMSAT BULELENG ( UPT BAPENDA PROVINSI BALI)
}

\author{
Luh Citra Damayanti \\ Jurusan Akuntansi Program Diploma III, \\ Universitas Pendidikan Ganesha, Singaraja \\ luhcitradamayanti@yahoo.com
}

\begin{abstract}
Abstrak
Penelitian ini untuk mengetahui tata cara penghitungan pajak bea balik nama kendaraan bermotor (roda dua) di Kantor SAMSAT Buleleng ( UPT Bapenda Provinsi Bali). Serta untuk mengetahui kebijakan apa yang diambil oleh Kantor SAMSAT Buleleng ( UPT Bapenda Provinsi Bali) dalam meningkatkan pendapatan pajak daerah.

Penelitian ini merupakan penelitian deskriptif kualitatif. Jenis data yang digunakan adalah data kuantitatif dan kualitatif, sedangkan metode pengumpulan data yang digunakan adalah wawancara, dokumentasi dan observasi. Data dianalisis dengan analisis deskriptif kuantitatif dan kualitatif.

Hasil penelitian ini menunjukkan bahwa bea balik nama kendaraan bermotor (roda dua) ada 2 jenis yaitu bea balik nama untuk pihak pertama dan untuk pihak kedua. Dimana tarif pengenaan pajaknya juga berbeda yang diatur oleh Peraturan Daerah Nomor 8 Tahun 2016
\end{abstract}

Kata kunci : Balik Nama,Pajak,Samsat

Abstract
This research is to know the procedure of calculating the tax of motor vehicle refund (two wheel) in SAMSAT Buleleng Office (UPT Bapenda Bali Province). And to find out what policies are taken by the Office of SAMSAT Buleleng (UPT Bapenda Bali Province) in increasing local tax revenues

This research is a qualitative descriptive research. Types of data used are quantitative and qualitative data, while data collection methods used are interviews, documentation and observation. Data were analyzed by quantitative and qualitative descriptive analysis

The results of this study indicate that the transfer of motor vehicle name (two-wheeled) there are 2 types namely the transfer of name for the first party and for the second party. Where the tax rates are also different which is regulated by Regional Regulation No. 8 of 2016

Keywords: transfer of title,tax,Samsat

\section{Pendahuluan}

Esensi dari keadilan di bidang perpajakan adalah keseimbangan antara hak negara dan hak warga negara pembayar pajak. Hak negara adalah untuk memperoleh pembayaran pajak oleh warga negara sesuai dengan ketentuan yang berlaku, tidak lebih dan tidak kurang. Hak wajib pajak adalah hak untuk dapat perlakuan yang adil dari negara dalam melaksanakan kewajibannya kepada negara tersebut dan hak untuk mendapat kepastian hukum apabila sudah memenuhi kewajibanya.

Berdasarkan analisa Thamrin Simanjuntak sebagaimana dikutip oleh Halim (2004) mengemukakan bahwa setiap daerah di Indonesia diberikan hak untuk melakukan otonomi daerah dengan memberikan kewenangan yang luas, Dimana Pendapatan Asli Daerah ini menggambarkan kemampuan daerah dalam mengelola hasil daerah sendiri. Pendapatan Asli Daerah tersebut terdiri dari : (1) Hasil Pajak Daerah ; (2) Hasil Retribusi Daerah ; (3) Hasil Perusahaan milik daerah dan hasil pengelolaan kekayaan daerah yang dipisahkan ; (4) lain-lain Pendapatan Asli Daerah yang besar. Adapun hasil pajak daerah pemerintahan provinsi terdiri dari : (1) Pajak Kendaraan Bermotor (PKB) ; (2) Bea Balik Nama Kendaraan Bermotor (BBNKB) ; (3) Pajak Bahan Bakar Kendaraan Bermotor (PBBKB) ; (4) Pajak Perusahaan Air Bawah Tanah dan Permukaan . 
Salah satu hasil pajak daerah pemerintah propinsi yang disebutkan diatas adalah BBNKB (Bea Balik Nama Kendaraan Bermotor). Adapun yang dimaksud dengan BBNKB adalah merupakan salah satu pungutan milik pemerintah propinsi yang termasuk dalam pajak daerah yang cukup besar kontribusinya dalam pemenuhan sumber-sumber penerimaan daerah.Setiap pemilik kendaraan haruslah mengetahui tentang Bea Balik Nama Kendaraan Bermotor ini dengan tujuan untuk memastikan keabsahan kepemilikan kendaraan bermotor tersebut.

Sehubungan dengan gambaran dan latar belakang tersebut, maka dapat dirumuskan masalah penelitian yaitu "Bagaimana tata cara penghitungan Bea Balik Nama Kendaraan Bermotor (Roda Dua) di Kantor SAMSAT Buleleng?"

\section{Metode Penelitian}

Pada rancangan penelitian hal pertama yang pertama kali dilakukan adalah menentukan lokasi penelitian dimana penulis melakukan penelitian pada Kantor SAMSAT Buleleng ( UPT Bapenda Provinsi Bali) yang beralamat di Jalan Jalan Laksamana Barat, Baktiseraga. Setelah lokasi penelitian ditentukan barulah peneliti melihat hal-hal apa sajakah yang terjadi di Kantor SAMSAT Buleleng yang berhubungan dengan bea balik nama kendaraan bermotor (roda dua). Setelah itu, peneliti dapat merumuskan masalah dari penelitian yang akan diambil. Setelah itu, peneliti membuat kajian teori dimana dari kajian teori inilah peneliti dapat mengetahui data-data apa saja yang dibutuhkan. Data yang digunakan dalam penelitian ini berupa data kuantitatif dan data kualitatif yang berasal dari hasil wawancara, dokumentasi dan observasi yang peneliti lakukan di Kantor SAMSAT Buleleng. Data yang telah diperoleh kemudian dianalisis menggunakan analisis deskriptif kualitatif. Dari pengolahan data tersebut, peneliti mendapatkan hasil penelitian dimana dari hasil penelitian ini nantinya bisa ditarik kesimpulan mengenai tata cara penghitungan bea balik nama kendaraan bermotor (roda dua) di Kantor SAMSAT Buleleng

\section{Hasil dan Pembahasan}

BBNKB merupakan salah satu pungutan milik pemerintah propinsi yang termasuk dalam pajak daerah yang cukup besar kontribusinya dalam pemenuhan sumber-sumber penerimaan daerah. Setiap pemilik kendaraan haruslah mengetahui tentang Bea Balik Nama Kendaraan Bermotor ini dengan tujuan untuk memastikan keabsahan kepemilikan kendaraan bermotor tersebut. Adapun prosedur yag harus dilakuakn wajib pajak saat melakukan bea balik nama kendaraan bermotor (rida dua) yakni :

1. Pemohon melengkapi berkas untuk kepentingan Bea Balik Nama Kendaraan Bermotor (BBNKB) berupa BPKB Asli dan Fotocopy, STNK Asli dan Fotocopy, Kwintansi Jual Beli Motor Asli dan Fotocopy, KTP Asli dan Fotocopy pemilik yg akan di lakukan Balik Nama Kendaraan Bermotor

2. Melakukan cek fisik kendaraan pada bagian cek fisik. Kemudian cocokkan hasil cek fisik berupa nomor rangka dan nomor mesin kendaraan dengan BPKB dan STNK yang asli

3. Kemudian pemohon meminta berkas di gedung Induk

4. Setelah itu pemohon ke loket BPKB untuk melakukan registrasi nomor BPKB.

5. Setelah itu pemohon ke loket 2 untuk meminta berkas

6. Kemudian ke bagian informasi untuk meminta blangko kosong yang nantinya harus diisi oleh pemohon yang baru dan di bagian informasi juga akan diberikan nomor antrian untuk di loket 1

7. Apabila blangko sudah diisi pemohon bisa langsung melakukan pembayaran di loket BRI

8. Dari Loket BRI langsung ke Loket 1. Selanjutnya akan diberikan kembali STNK asli serta bukti pajak akan diberikan kembali kepada anda. Untuk proses pengambilan BPKB ini umumnya bisa mencapai sekitar 1 bulan dan pengambilannya harus membawa nomor ticket BPKB berserta KTP asli.

Menurut Peraturan Daerah Nomor 8 Tahun 2016 Tentang Perubahan kedua Atas Peraturan Daerah Provinsi Bali Nomor 1 Tahun 2011 Tentang Pajak Daerah yang diraikan pada pasal 7 menyatakan bahawa :

(1) Tarif PKB pribadi ditetapkan dengan cara sebagai berikut : 
a. Untuk kepemilikan kendaraan bermotor roda dua dan roda tiga dibawah $250 \mathrm{cc}$ pertama sebesar $1,5 \%$ ( satu koma lima persen ) ;

b. Untuk kepemilikan kendaraan bermotor roda dua dan roda tiga sebagaimana dimaksud pada huruf a , kedua dan seterusnya ditetapkan secara progresif yaitu :

- Kendaraan kepemilikan kedua sebesar 2\%

- Kendaraan kepemilikan ketiga sebesar 2,5\% (dua koma lima persen)

- Kendaraan kepemilikan keempat sebesar 3\% (tiga persen)

- Kendaraan kepemilikan kelima dan seterusnya sebesar 3,5\% (tiga koma lima persen)

\section{Kesimpulan dan Saran}

Adapun kesimpulan yang didapatkan dari penelitian ini BBNKB merupakan singkatan dari Bea Balik Nama Kendaraan Bermotor. Dimana BBNKB adalah salah satu pungutan milik pemerintah propinsi yang termasuk dalam pajak daerah yang cukup besar kontribusinya dalam pemenuhan sumber-sumber penerimaan daerah. Penghitungan bea balik nama kendaraan bermotor (roda dua) diatur dalam Peraturan Daerah Nomor 8 Tahun 2016 Tentang Perubahan kedua Atas Peraturan Daerah Provinsi Bali Nomor 1 Tahun 2011 Tentang Pajak Daerah yang mudah dipahami

Dalam penghitungan BBNKB , untuk mencari nilai BBN (Bea Balik Nama) yaitu dengan cara $1 \%$ x NJKB (Nilai Jual Kendaraan Bermotor). Setelah mendapatkan hasil maka nanti akan dijumlahkan dengan PKB dan SWDKLLJ. Total dari penghitungan ini nantinya akan dijumlahkan dengan total biaya STNK, Plat dan BPKB. Hasil dari semua perhitungan ini merupakan total yang harus dibayar oleh wajib pajak yang melakukan balik nama kendaraan bermotor (roda dua).

\section{DAFTAR PUSTAKA}

Y. Pudyatmoko, Penghantar hukum pajak, Jogjakarta, Maret 2009

\section{Undang-Undang Republik Indonesia Nomor 18 Tahun 1997 Tentang Pajak Daerah Dan Retribusi Daerah}

\section{Undang-Undang Republik Indonesia Nomor 28 Tahun 2009 tentang pajak daerah} dan retribusi daerah beserta penjelasannya

Adriani dalam santoso brotodihardjo, Penghantar IImu Hukum Pajak, Tahun 1991 Marihot $\mathrm{p}$. Siahaan, Pajak daerah dan retribusi daerah, Jakarta, PT raja grafindo persada, tahun 2005

Undang-undang nomor 34 tahun 2000 tentang perubahan undang-undang nomor 18 tahun 1997 tentang pajak daerah dan retribusi daerah

Bohari. Pengantar perpajakan. Ghalia Indonesia, Jakarta 1985

Azhari. Perpajakan I (pajak Penghasilan). UR Press Pekanbaru, tahun 2010

Mardiasmo. Perpajakan edisi Revisi 2008

Sugiyono. 2012. Metode Penelitian Kuantitatif Kualitatif. Bandung : Alfabeta

Peraturan Daerah Nomor 8 Tahun 2016 Tentang Perubahan kedua Atas Peraturan Daerah Provinsi Bali Nomor 1 Tahun 2011 Tentang Pajak Daerah

Purnamawati, I.G.A. 2014. Pelaksanaan Peraturan Daerah Nomor 7 Tahun 2011 volume 9. Nomor 1. http://journal.unnes.ac.id/nju/index.php/pandecta 